\title{
Article
}

http://dx.doi.org/10.11646/phytotaxa.175.5.7

\section{The first squamulose Thelocarpon species (Thelocarpaceae, Ascomycota) discovered in the biological soil crusts in the Bolivian Andes}

\author{
ADAM FLAKUS ${ }^{1 *} \&$ MARTIN KUKWA ${ }^{2}$ \\ ${ }^{1}$ Laboratory of Lichenology, W. Szafer Institute of Botany, Polish Academy of Sciences, \\ Lubicz 46, PL-31-512 Krakow, Poland; e-mail: a.flakus@botany.pl \\ ${ }^{2}$ Department of Plant Taxonomy and Nature Conservation, University of Gdańsk, \\ Wita Stwosza 59,PL-80-308 Gdańsk, Poland; e-mail: dokmak@ug.edu.pl \\ *Corresponding author: a.flakus@botany.pl
}

\begin{abstract}
Thelocarpon andicola, a new terricolous species from the tropical Andes in Bolivia is described in this paper. This is the first member of the genus with squamulose to placodioid and yellow pruinose thallus, which is further characterized by non-amyloid hymenial gel, branched paraphyses, amyloid asci without visible mass axiale and broadly ellipsoidal ascospores.
\end{abstract}

Key words: biodiversity, lichenized fungi, Neotropics, Pezizomycotina, South America, taxonomy

\section{Introduction}

Thelocarpon Nylander (1853: 318) is represented by about 20 species occurring on soil, wood or rocks, with some species occasionally or commonly being lichenicolous (Magnusson 1936; Salisbury 1966, 1974; Poelt \& Vězda 1977; McCarthy \& Kantvilas 2009; Orange et al. 2009). The genus is currently classified in family Thelocarpaceae, but its precise phylogenetic placement within Pezizomycotina remains still unknown (Reeb et al. 2004; Miądlikowska et al. 2014). The well-documented high plasticity of ascomata (from perithecioid to apothecioid) and ascus types (with or without axial mass) seem to suggest the polyphyly of Thelocarpon (Salisbury 1966, 1974; Poelt \& Hafellner 1975), however, the recent molecular study by Lumbsch et al. (2009) has finally proved its monophyly.

Thelocarpon is characterized by apothecioid or perithecioid ascomata, which can be yellow-green pruinose in some species due to the presence of pulvinic acid derivatives, by the hamathecium of simple to branched paraphyses (in some species absent) with periphysoids present or not, and flask-shaped, multispored asci containing hyaline, simple or 1-septate ascospores. The genus has also quite diverse nutritional strategy. Some species are clearly lichenforming and its ascomata are developing in thallus verrucae where the algal sheath is present (sometimes sterile verrucae also contain algal cells), however other species can be fortuitously lichenized or clearly non-lichen-forming (Salisbury 1966; Knudsen \& Lumbsch 2007; McCarthy \& Kantvilas 2009; Orange et al. 2009).

During our ongoing lichenological studies carried out in Bolivia (e.g. Flakus \& Wilk 2006; Flakus 2009; Flakus et al. 2008, 2011, 2012; Kukwa \& Flakus 2009; Kukwa et al. 2012, 2013), an undescribed species of Thelocarpon was found in the Andes. The species has a unique morphology as it is the first member of the genus with fully lichenized squamulose to placodioid thallus, and it is described below.

\section{Material and Methods}

The study based on material collected by the authors and deposited in KRAM, LPB, UGDA, and private herbarium of A. Flakus. The morphology and the anatomy were examined using standard stereo and compound microscopes (Nikon SMZ 800, Nikon Eclipse 80i DIC). Hand sections and squash mounds were examined in tap water, $10 \%$ solution of potassium hydroxide (K) or lactophenol cotton blue (LPCB). The amyloidity of lichen structures were studied using 


\section{Acknowledgements}

We are greatly indebted to Dr. Kerry Knudsen (Riverside) and Dr. Sergio Pérez-Ortega (Madrid) for reviewing the manuscript and constructive comments. Special thanks go to Rosa I. Meneses Q., the Director of Herbario Nacional de Bolivia, Instituto de Ecología, Universidad Mayor de San Andrés, La Paz, for generous cooperation. This research received support from the National Centre for Research and Development (NCBiR) in Poland, under the LIDER Programme for the years 2010-2013 (no. 92/L-1/09) and also from the W. Szafer Institute of Botany of the Polish Academy of Sciences through the statutory funds.

\section{References}

Awasthi, D.D. (1991) A key to the microlichens of India, Nepal and Sri Lanka. Bibliotheca Lichenologica 40: 1-340.

Awasthi, D.D. \& Singh, K.P. (1975) Three new taxa of lichens from Palni Hills, India. Geophytology 5: 39-42.

Bouly de Lesdain, M. (1914) Recherches sur les Lichens des Environs de Dunkerque: Premier Supplement. Imp. P. Michel, Dunkerque, $189 \mathrm{pp}$.

Culberson, C.F. \& Kristinsson, H. (1970) A standardized method for the identification of lichen products. Journal of Chromatography 46: $85-93$.

http://dx.doi.org/10.1016/s0021-9673(00)83967-9

Eitner, E. (1901) Zweiter Nachtrag zur schlesischen Flechtenflora. Jahresbericht der Schlesischen Gesellschaft für Vaterländische Kultur 78: 5-27.

Flakus, A. (2009) Aspidothelium lueckingii: a new lichenized fungus from Bolivia. Nova Hedwigia 88: 139-143. http://dx.doi.org/10.1127/0029-5035/2009/0088-0139

Flakus, A. \& Wilk, K. (2006) Contribution to the knowledge of the lichen biota of Bolivia. Journal of the Hattori Botanical Laboratory 99: 307-318.

Flakus, A., Ahti, T., Kukwa, M. \& Wilk, K. (2008) New and interesting records of Cladonia and their lichenicolous fungi from the Andean cloud forest in Bolivia. Annales Botanici Fennici 45: 448-454. http://dx.doi.org/10.5735/085.045.0603

Flakus, A., Elix, J.A., Rodriguez, P. \& Kukwa, M. (2011) New species and records of Lepraria (Stereocaulaceae, lichenized Ascomycota) from South America. Lichenologist 43: 57-66. http://dx.doi.org/10.1017/s0024282910000502

Flakus, A., Rodriguez Saavedra, P. \& Kukwa, M. (2012) A new species and new combinations and records of Hypotrachyna and Remototrachyna from Bolivia. Mycotaxon 119: 157-166. http://dx.doi.org/10.5248/119.157

Flotow, J. (1847) Sphaeropsis Fw., eine neue deutsche Flechtengattung. Botanische Zeitung 5: 65-66.

Knudsen, K. \& Lumbsch, H.T. (2007) Thelocarpon. In: Nash III, T.H., Gries, C. \& Bungartz, F. (Eds.) Lichen Flora of the Greater Sonoran Desert Region, Volume 3. Lichens Unlimited, Arizona State University, Tempe, Arizona, pp. 301-302.

Kocourková-Horáková, J. (1998) Distribution and ecology of the genus Thelocarpon (Lecanorales, Thelocarpaceae) in the Czech Republic. Czech Mycology 50: 271-302.

Kukwa, M. \& Flakus, A. (2009) Lepraria glaucosorediata sp. nov. (Stereocaulacae, lichenized Ascomycota) and other interesting records of Lepraria. Mycotaxon 108: 353-364.

http://dx.doi.org/10.5248/108.353

Kukwa, M., Etayo, J. \& Flakus, A. (2012) Plectocarpon stereocaulicola (Roccellaceae, Ascomycota), a new lichenicolous fungus from Bolivia. Lichenologist 44: 479-482. http://dx.doi.org/10.1017/s0024282912000151

Kukwa, M., Schiefelbein, U. \& Flakus, A. (2013) A contribution to the lichen family Graphidaceae (Ostropales, Ascomycota) of Bolivia. Herzogia 26: 231-252. http://dx.doi.org/10.13158/heia.26.2.2013.231

Lumbsch, H.T., Zimmermann, D.G. \& Schmitt, I. (2009) Phylogenetic position of ephemeral lichens in Thelocarpaceae and Vezdaeaceae (Ascomycota). Bibliotheca Lichenologica 100: 389-398.

Lutzoni, F., Pagel, M. \& Reeb, V. (2001) Major fungal lineages are derived from lichen symbiotic ancestors. Nature 411: 937-940. http://dx.doi.org/10.1038/35082053 
Magnusson, A.H. (1936) Acarosporaceae und Thelocarpaceae. In: Zahlbruckner, A. (Ed.) Dr. L. Rabenhorst's Kryptogamen Flora von Deutschland, Öesterreich und der Schweiz, 2nd, Band 9 (5/1). Akademische Verlagsgesellschaft M.B.H., Leipzig, pp. 1-318.

McCarthy, P.M. \& Kantvilas, G. (2009) Thelocarpaceae. In: McCarthy, P.M. (Ed.) Flora of Australia Volume 57, Lichens 5. ABRS and CSIRO Publishing, Canberra and Melbourne, pp. 563-569.

Miądlikowska, J., Kauff, F, Högnabba, F., Oliver, J.C., Molnár, K., Fraker, E., Gaya, E., Hafellner, J., Hofstetter, V., Gueidan, C., Otáloraa, M.A.G., Hodkinson, B., Kukwa, M., Lücking, R., Björk, C., Sipman, H.J.M., Burgaz, A.R., Thell, A., Passo, A., Myllys, L., Goward, T., Fernández-Brime, S., Hestmark, G., Lendemer, J., Lumbsch, H.T., Schmull, M., Schoch, C.L., Sérusiaux, E., Maddison, D.R., Arnold, A.E., Lutzoni, F. \& Stenroos, S. (2014) A multigene phylogenetic synthesis for the class Lecanoromycetes (Ascomycota): 1307 fungi representing 1139 infrageneric taxa, 317 genera and 66 families. Molecular Phylogenetics and Evolution 79: 132-168. http://dx.doi.org/10.1016/j.ympev.2014.04.003

Moon, K.H. \& Aptroot, A. (2009) Pyrenocarpous lichens in Korea. Bibliotheca Lichenologica 99: 297-314.

Nylander, W. (1853) Lichenes Algerienses novi. Annales des Sciences Naturelles 20: 315-320.

Nylander, W. (1855) Essai d'une nouvelle classification des lichens (second mémoire). Mémoires de la Société Impériale des Sciences Naturelles de Cherbourg 3: 161-202.

http://dx.doi.org/10.5962/bhl.title.50222

Orange, A., James, P.W. \& White, F.J. (2001) Microchemical methods for the identification of lichens. British Lichen Society, London, $101 \mathrm{pp}$.

Orange, A., Watson, M.F., James, P.W. \& Moore, D.M. (2009) Thelocarpon Nyl. (1853). In: Smith, C.W., Aptroot, A., Coppins, B.J., Fletcher, A., Gilbert, O.L., James, P.W. \& Wolseley, P.A (Eds.) The lichens of Great Britain and Ireland. The British Lichen Society, London, pp. 884-888.

Poelt, J. \& Hafellner, J. (1975) Schlauchpforten bei der Flechtengattung Thelocarpon. Phyton 17: 67-77.

Reeb, V., Lutzoni, F. \& Roux, C. (2004) Contribution of RPB2 to multilocus phylogenetic studies of the Euascomycetes (Pezizomycotina, Fungi) with special emphasis on the lichen-forming Acarosporaceae and evolution of polyspory. Molecular Phylogenetics and Evolution 32: 1036-1060.

http://dx.doi.org/10.1016/j.ympev.2004.04.012

Salisbury, G. (1953) The genus Thelocarpon in Britain. North Western Naturalist 1953: 66-76.

Salisbury, G. (1966) A monograph of the lichen genus Thelocarpon Nyl. Lichenologist 3: 175-196. http://dx.doi.org/10.1017/s0024282966000197

Salisbury, G. (1974) A monograph of the fungal genus Ahlesia Fuckel. Nova Hedwigia 25: 683-690.

Vondrák, J., Palice, Z., Khodosovtsev, A. \& Postoyolkin, S. (2010) Additions to the diversity of rare or overlooked lichens and lichenicolous fungi in Ukrainian Carpathians. Chornomorski Botanical Journal 6: 6-34. 